\title{
Aleksandra Twardowska
}

atwardowska@umk.pl

http://dx.doi.org/10.18778/2544-1795.01.17

\section{JĘZYK MÓWIONY BAŁKAŃSKICH ŻYDÓW SEFARDYJSKICH W ŚWIETLE NAJNOWSZYCH BADAŃ SOCJOLINGWISTYCZNYCH}

\author{
Ивана Вучина Симовић, Јеврејско-шпански језик на Балкану. Прилози \\ историјској социолингвистици, ФИЛУМ, Kragujevac 2016, ss. 338.
}

Opisu języka żydowsko-hiszpańskiego w krajach byłej Jugosławii dokonywano wielokrotnie, począwszy od pionierskich prac Kalmiego Baruha sprzed II wojny światowej, poprzez powojenne artykuły Edwarda Stankiewicza lub Isaka Papo. Rozważania na temat języka mówionego bałkańskich Sefardyjczyków pojawiły również się w imponującej monografii Muhameda Nezirovicia poświęconej sefardyjskiej literaturze (1995). Językowi żydowsko-hiszpańskiemu w Bośni poświęcono cały tom zbiorowy wydany w 2015 roku, w Sarajewie, w którym, obok klasycznych już prac, znalazły się artykuły współczesnych badaczy, m.in.: Eliezera Papo, Katji Šmid i Dimitrije Pešicia. Jednak wydana w zeszłym roku propozycja Ivany Vučiny Simović, po którą sięgnęłam z wielkim zainteresowaniem, jest jednym z rzadkich przykładów w krajach byłej Jugosławii monograficznych opisów języka żydowsko-hiszpańskiego z naciskiem na aspekty socjolingwistyczne.

Głównym zagadnieniem monografii jest kondycja żydowsko-hiszpańskiego na terenie byłej Jugosławii przed 1941 rokiem, a jej opis oscyluje wokół dwóch głównych socjolingwistycznych zagadnień i socjologii języka - zachowania języka (serb. održavanje jezika, ang. language maintenance) i jego zamiany (serb. zamena jezika, ang. language shift) i uzupełniony jest rozważaniami z zakresu historii społecznej i kulturowej oraz psychologii języka. Opis dotyczy czterech głównych ośrodków sefaryjskich na terenach Jugosławii przed II wojną światową: Belgradu, Sarajewa, Bitoli i Skopje. Materiały źródłowe, które wykorzystuje Autorka, pozyskane zostały z instytucji i archiwów na terenie byłej Jugosławii i Izraela.

Bardzo słusznie we wstępnych rozważaniach Vučiny Simović zwraca uwagę na wciąż wzbudzający wśród badaczy kontrowersje problem nazwy języka mówionego Żydów sefardyjskich, podkreślając, iż zarówno w tradycji, jak i w badaniach używano wielu glottonimów na jego określenie: djudezmo, judezmo, espanyol/shpanyol, djudio, ladino, haketiya etc., przy czym nazwa ladino w czasach współczesnych jest najbardziej rozpowszechniona i używana zamiennie z nazwą ,żydowsko-hiszpański”. Autorka jednak decyduje się filologiczną nazwę (zgodnie z postulatem Pierwszego Sympozjum Studiów Sefardyjskich w 1964 roku) na oznaczenie języka mówionego Żydów sefardyjskich. Uzasadnia również użycie terminów ,język serbski/serbsko-chorwacki” ze świadomym pominięciem glottonimu ,język macedoński”.

Monografię otwiera rozdział poświęcony teoretycznym rozważaniom na temat języka i jego użytkowników w kontekście modernizmu, nacjonalizmu oraz tożsamości językowej. Autorka opisuje dotychczasowy stan badań nad ideologiami i postaw wobec języka, w tym: ideologię języków narodowych, języków standardowych i standaryzacji języka (w modelu racjonalnym i romantycznym, nacjonalistycznym i postmodernistycznym).

Najbardziej istotny dla tematu monografii jest oczywiście stan badań dotyczący zachowania i zamiany języka oraz procesów z nimi powiązanych w (np. szerzenie i zanikanie języka z punktu widzenia języków grup mniejszości i większości). Vučina Simović przywołuje teorie Uriela Weinreicha dotyczące zagadnienia languages in contact, Susan Gal, Johna Edwardsa, Kennetha Hyltenstama czy Christophera Strouda. Zahacza również o zagadnienie śmierci języka przejęte z badań 
społeczno-politycznych (co w przypadku badań nad językami żydowskimi łączy się zwykle z końcowym efektem szybkiego zaniku języka w skutek Holokaustu). Sporo uwagi Autorka poświęca teorii zamiany języka i etapom tego procesu według Francisco Gimeno Menédeza i Marii Victorii Gimeno Menédez (od jednojęzyczności poprzez dwujęzyczność z coraz większymi kompetencjami w języku większości i malejącymi w języku mniejszości, aż po jednojęzyczność w języku większości). Na podstawie badań Hiszpanów Autorka sporządziła interesujący schemat ilustrujący proces zamiany języka, jaki zaszedł w sześciu generacjach belgradzkich Żydów sefardyjskich, w którym ostatni etap objął jedno-, serbskojęzycznych urodzonych po II wojnie światowej.

W tym samym rozdziale pojawia się omówienie procesów i zjawisk pobocznych dla tematu, a jednak stanowiących istotne jego uzupełnienie, jak: regeneracja języka, ożywienie języka, rewitalizacja języka, zmiana kierunku zamiany języka czy zjawisko językowej lojalności. Vučina Simović zamieszcza również swoją listę czynników, które wpływają na proces zamiany/utrzymania języka: demografia, socjologia, socjolingwistyka, psychologia, historia, polityka/prawo/władza, geografia, edukacja, religia, ekonomia oraz media. Dla opisu języka żydowsko-hiszpańskiego na Bałkanach cenne okazały się również studia Joshuy Fishmana nad stanowiskami użytkowników wobec własnego języka, jak: wartościowanie języka, stopnień troski o język i jego planowanie oraz świadomość języka i wiedza o nim.

Drugą istotną, po rozważaniach teoretycznych, podstawą opisu kondycji języka jest historia Sefardyjczyków, ich sytuacja społeczna i kulturowa od ich przybycia na tereny imperium otomanskiego do wybuchu II wojny światowej na terenach byłej Jugosławii i temu poświęcony jest cały trzeci rozdział. Autorka opisuje położenie gmin żydowskich w czasach dominacji tureckiej, ówczesną organizację życia społecznego, religijnego, rodzinnego w żydowskich mahalach, w których, mimo braku przymusu osiedlania się w gettach, Żydzi sefardyjscy prowadzili rodzaj kolektywnego życia. Autorka wymienia szereg zjawisk życia sefardyjskiego, które wpłynęły na utrzymanie języka żydowsko-hiszpańskiego przez cały okres osmańskiej dominacji, m.in.: patriarchalne modele rodzin, ograniczona liczba wykonywanych zawodów (handlarze, drobni rzemieślnicy, właściciele kantorów czy ludowi aptekarze), edukacja ograniczona tylko do religijnego kształcenia chłopców w szkołach typu Talmud-Tora, ograniczona przestrzeń życiowa sefardyjskich kobiet.

Kolejny istotny okres to czas modernizacji gmin sefardyjskich, w wyniku której obserwowało się procesy akulturacji, a nawet asymilacji począwszy od końca XIX wieku, co z kolei wywołało proces ubożenia języka żydowsko-hiszpańskiego. Vučina Simović słusznie wskazuje na różnicę w tempie zachodzenia tych zmian w ośrodkach sefardyjskich: od najszybciej asymilujących się sefardyjskich mieszkańców Belgradu (od XIX wieku), aż do żyjących w izolacji kulturowej do 1918 roku i trudnych warunkach materialnych Sefardyjczyków z ośrodków macedońskich. Niemniej jednak wśród nowych zjawisk, które nastały z modernizacją i przyczyniły się do zamiany języka, Autorka wymienia sposób życia, zachowania, a nawet ubierania, zanik kultury patriarchalnej i ortodoksyjnej, zasiedlanie nieżydowskich dzielnic miast, pojawienie się pierwszych generacji sefardyjskich świeckich intelektualistów, początki świeckiej edukacji (najszybciej w Belgradzie w wyniku państwowej, serbskiej, reformy edukacji, w Sarajewie od czasów austro-węgierskiej okupacji i w Macedonii wraz z działalnością sieci szkół Alliance Israélite Universelle, a następnie wraz z włączeniem tamtejszych Sefardyjczyków do edukacji państwowej od 1918 roku). Bardzo ważnym aspektem jest również podkreślana przez Autorkę emancypacja kobiet sefardyjskich w Belgradzie i Sarajewie, ich uczestnictwo w edukacji świeckiej, podstawowej i wyższej, zakładanie przez nie żeńskich towarzystw i organizacji.

Niemało uwagi Vučina Simović poświęca również odnowionym kontaktom jugosłowiańskich (bałkańskich, orientalnych) Sefardyjczyków z ówczesną Hiszpanią i kampanii zapoczątkowanej w pierwszych latach XX wieku przez Angela Pulido, w myśl której bałkańscy Sefardyjczycy to hiszpańscy Żydzi czy wręcz Hiszpanie wypędzeni z dawnej ojczyzny. Aktywny odzew na kampanię po stronie jugosłowiańskiej Autorka zauważa wśród intelektualistów sefardyjskich takich jak Benko S. Davičo, Abraham Cappon czy Kalmi Baruh.

Dla Autorki równie ważne są kwestie ruchów i ideologii w środowisku żydowskim sprzed 1941 roku, które miały niemały wpływ na stosunek do języka żydowsko-hiszpańskiego: syjonizm, 
aszkenazyjsko-sefardyjski, (podkreślający wiodącą rolę odrodzonego języka hebrajskiego) z jednej i tzw. ruch sefardyjski (wzywający do pielęgnacji języka żydowsko-hiszpańskiego i przypisujący mu rolę wyznacznika tożsamości sefardyjskiej) z drugiej strony.

Przegląd historyczno-społeczno-kulturowy kończy się opisem zagłady wspólnot żydowskich w czasie II wojny światowej i próba ich rewitalizacji po 1945 roku.

W kolejnej części Autorka podejmuje się konkretnego opisu zamiany/zachowania języka żydowsko-hiszpańskiego w wyżej wspomnianych czterech ośrodkach sefardyjskich na Bałkanach. Jak zaznacza, do końca XIX wieku pełnił rolę języka mówionego grup w każdym z tych ośrodków, choć w jego korpusie pojawiały się wpływy języka hebrajskiego, tureckiego, włoskiego, francuskiego, niemieckiego czy, w końcowym etapie, serbskiego/serbsko-chorwackiego. Zwraca przy tym uwagę na różną sytuację językową w opisywanych ośrodkach: na zamianę języka mówionego w Belgradzie na początku XX wieku i utrzymanie żydowsko-hiszpańskiego do 1941 roku w Sarajewie (choć w procesie stopniowego zaniku) i szczególnie mocnej jego kondycji w Bitoli i Skopje. Vučina Simović bogato ilustruje opis sytuacji językowej artykułami z lokalnej prasy żydowskiej, przede wszystkim serbskiej i bośniackiej, oraz statutami towarzystw i organizacji żydowskich sprzed II wojny światowej. Jednocześnie wskazuje na jeszcze jedną, istotną rolę żydowsko-hiszpańskiego, poza funkcją języka komunikacji wewnętrznej: rolę języka ustnej tradycji sefardyjskiej, języka, w którym powstawała sefardyjska twórczość ludowa obejmująca romance, kantikas, endechas, koplas itp.

Według Autorki procesowi zamiany języka (szczególnie w Belgradzie i Sarajewie|) towarzyszyły takie czynniki, jak: powiększający się repertuar zawodowy Sefardyjczyków, reformy szkolnictwa państwowego, rosnący udział Sefardyjczyków w życiu społecznym, kulturalnym i politycznym otoczenia (przy czym Żydzi serbscy już pod koniec XIX wieku określali się jako „Serbowie wiary mojżeszowej").

W tym samym rozdziale Vučina Simović powraca do roli Sefardyjek w procesie zmian, jakim ulegał żydowsko-hiszpański: z jednej strony to one były strażniczkami tradycji sefardyjskiej i tym samym przekazywały język z pokolenia na pokolenie (ostatnie przedwojenne pokolenia przynajmniej bierną znajomość języka zawdzięczały matkom i babkom, mężczyźni częściej posługiwali się serbsko-chorwackim i innymi językami). Wspomina również o działalności i twórczości Laury Papo Bohorety, która gromadziła próbki sefardyjskiego folkloru, języka, pisała również w tym języku dramaty, opowiadania i poezję. $Z$ drugiej zaś strony postępująca emancypacja i wykształcenie świeckie Sefardyjek sprawiały, że i nawet w środowisku kobiet pojawiła się (np. w okresie międzywojennym w Sarajewie) dwujęzyczność i częste zjawisko interferencji między używanymi językami.

Innym czynnikiem wpływającym również na dynamikę sytuacji językowej Sefardyjczyków wymienione to według Autorki małżeństwa mieszane (sefardyjsko-aszkenazyjskie i rzadkie jednak przed 1941 rokiem te żydowsko-nieżydowskie).

Ta część monografii wzbogacona także jest tabelami z danymi statystycznymi sporządzonymi na podstawie ankiety „Moja rodzina” (przeprowadzonej w latach 1979-1980, przechowywanej w Historycznym Muzeum Żydowskim w Belgradzie) o języku/językach, którymi posługiwały się generacje sefardyjskie w Belgradzie i Sarajewie urodzone między 1840 a 1942 rokiem.

Ostatni rozdział poświęcony został ideologiom językowym w sefardyjskich wspólnotach byłej Jugosławii przed II wojną światową. Jak podkreśla w nim Autorka, Sefardyjczycy na Bałkanach do początku XX wieku nie byli świadomi pochodzenia swojego języka, określając go po prostu mianem ,języka żydowskiego". Wraz ze wzrostem wiedzy na temat języka żydowsko-hiszpańskiego wśród jego użytkowników do 1941 roku pojawiło się kilka znaczących językowych ideologii, m.in.: pod wpływem opisanej przez Vučinę Simović kampanii promującej zacieśnianie kontaktów z Hiszpanią, żydowsko-hiszpański traktowano jako ,zepsuty” wariant hiszpańskiego, postulując jego zbliżenie do kastylijskiego standardu. Język Sefardyjczyków i wśród nich samych opisywany bywał jako ,język zubożały i wymierający”, choć podkreślano przy tym jego dobrą kondycję w Bitoli i Skopje. Przed II wojną światową zauważano, że na Bałkanach z językiem konkurują inne języki: serbsko-chorwacki, bułgarski, francuski w Macedonii, jako język pierwszej świeckiej tam żydow- 
skiej edukacji, czy hebrajski jako język mający scalić wszystkie grupy żydowskie wedle ideologii syjonistycznej. Każda z językowych opcji ideologicznych została przez Autorkę zilustrowana cytatami z ówczesnej prasy żydowskiej, przy czym słusznie podkreślone zostało to, który organ prasowy którą z postaw szczególnie promował (np. syjonistyczny „Gideon” wspierający hebraizację lub „Jevrejski život” jako tuba ruchu sefardyjskiego w Bośni postulująca pielęgnację języka żydowsko-hiszpańskiego i lojalność wobec niego). W tej części nieco zabrakło jedynie wzmianki o konferencji sefardyjskiej, jaka odbyła się w Sarajewie w latach 20. XX wieku, w czasie której sytuacja językowa mniejszości żydowskiej była jednym z dyskutowanych punktów, a rezolucje dotyczące języka żydowsko-hiszpańskiego opisywane w lokalnej prasie żydowskiej, m.in. w artykułach Eliezera Leviego.

Monografia Ivany Vučiny Simović jest pracą kompletną: oparty na solidnie przygotowanej części teoretycznej opis sytuacji językowej Sefardyjczyków w Belgradzie, Sarajewie oraz Bitoli i Skopje jest szczegółowy, przedstawiony w sposób systematyczny, interesujący, uwzględnia wszystkie różnice między badanymi ośrodkami. Widać ogrom pracy Autorki w docieraniu do materiałów, ich selekcji, trafnym wyborze jako ilustracji do rozważań. Tłumaczenia cytatów na język serbski z języka żydowsko-hiszpańskiego zostały przygotowane przez Autorkę, a dodatkowo, te, które w oryginale były sporządzone w alfabecie Rasziego (np. teksty z czasopisma „La Alborada” lub „El amigo del pueblo”), Vučina Simović transliterowała na łacinkę według zasad przyjętych w czasopiśmie „Aki Yerushalayim”. Zawarte w publikacji statuty, rękopisy i ankiety czynią ją dodatkowo wartościową. Bibliografia jest niezwykle obszerna, zawiera pozycje teoretyczne z zakresu socjolingwistyki, pozycje obejmujące analogiczne studia nad innymi językami, bogaty zbiór pozycji historycznych i opracowań dotyczących sefardyjskich wspólnot na Bałkanach. Uzasadnione byłoby wydanie publikacji w angielskiej lub hiszpańskiej wersji językowej (szczególnie jej praktycznej części), ponieważ jest ona niezwykle ważnym wkładem do badań nad diasporowymi językami żydowskimi, więc z pewnością wzbudziłaby zainteresowanie badaczy poza krajami byłej Jugosławii. 